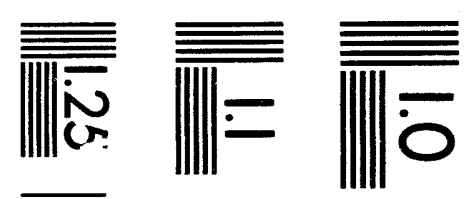

$$
\begin{aligned}
& \text { 柿 }
\end{aligned}
$$

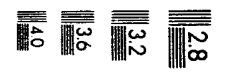

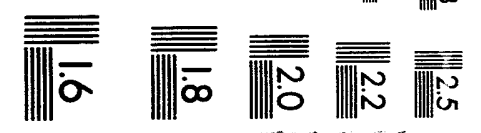



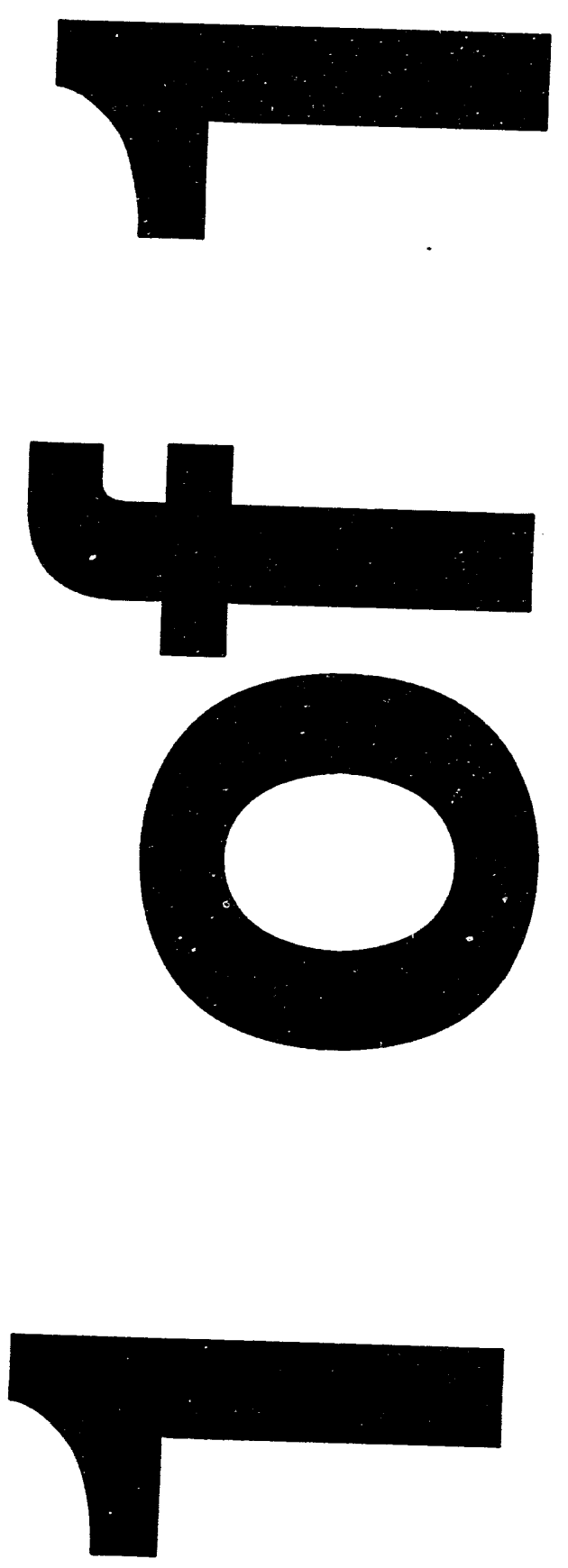


\title{
ALIPHATIC HYDROCARBONS IN SEDIMENT CORES FROM THE SOUTHERN BASIN OF LAKE MICHIGAN*
}

\author{
Paul V. Doskey
}

Environmental Research Division

Argonne National Laboratory

Argonne, Il 60439

\section{Anders W. Andren}

Water Chemistry Program

University of Wisconsin

Madison, WI 53706

\section{DISCLAIMER}

\begin{abstract}
This report was prepared as an account of work sponsored by an agency of the United States Government. Neither the United States Government nor any agency thereof, nor any of their employees, makes any warranty, express or implied, or assumes any legal liability or responsibility for the accuracy, completeness, or usefulness of any information, apparatus, product, or process disclosed, or represents that its use would not infringe privately owned rights. Reference herein to any specific commercial product, process, or service by trade name, trademark, manufacturer, or otherwise does not necessarily constitute or imply its endorsement, recommendation, or favoring by the United States Government or any agency thereof. The views and opinions of authors expressed herein do not necessarily state or reflect those of the United States Government or any agency thereof.
\end{abstract}

\section{RECEIVED \\ APR 181994 \\ OSTI}

October 1991

\begin{abstract}
*This investigation was supported by the University of Wisconsin Sea Grant Institute through Federal Grant NA 800-AA-00086, Project R/MW-13 from the National Sea Grant College Program, National Oceanic and Atmospheric Administration, U. S. Department of Commerce. The writing of this manuscript was sponsored by the U.S. Department of Energy, Office of Energy Research, Office of Health and Environmental Research, under contract W-31-1.09-ENG-38.
\end{abstract}

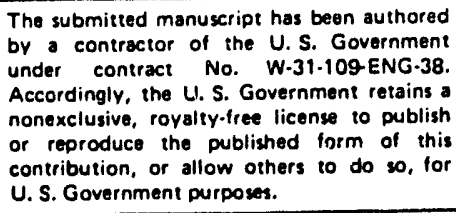


ABSTRACT. Aliphatic hydrocarbons in sediments of the southern basin of Lake Michigan have planktonic, terrigenous, and petroleum residue origins. Surficial sediments collected near the eastern shore in $60-80 \mathrm{~m}$ of water contained more petroleum residue and planktonic hydrocarbons and exhibited less terrigenous character than sediments collected from the deepest location in the basin. Petroleum residue inputs have increased since 1900 as evidenced by a change in the flux of an unresolved complex mixture (UCM) of hydrocarbons from $6 \mathrm{ng} / \mathrm{cm}^{2} \cdot \mathrm{yr}$ to a flux of approximately $100 \mathrm{ng} / \mathrm{cm}^{2} \cdot \mathrm{yr}$ in 1980 . Sediment profiles of the UCM exhibited subsurface concentration maxima that may be due to reduced inputs of combustion products or feeding by oligochaetes. Profiles of $n-C_{17}$ and pristane indicated that planktonic $n$-alkanes undergo degradation in the aerobic, mixed zone of the sediments.

ADDITIONAL INDEX WORDS: Petroleum hydrocarbons, n-alkanes, hydrocarbon geochronologies, lake sediments. 


\section{INTRODUCTION}

Investigations of the distribution of aliphatic hydrocarbons in freshwater lake sediments indicate that these hydrocarbons have both biogenic and anthropogenic origins (Giger et al. 1974 and 1980, Wakeham and Carpenter 1976, Meyers and Takeuchi 1979, Wakeham and Farrington 1980). Terrestrial plants and plankton are the most prevalent biogenic sources. Anthropogenic sources include activities associated with the transportation, storage, processing, and combustion of fossil fuels. Hydrocarbons from these sources have unique chemical signatures. For example, the predominant $\mathrm{n}$-alkanes in plankton are $\mathrm{C}_{15}, \mathrm{C}_{17}$, and $\mathrm{C}_{19}$ (Clark and Blumer 1967, Blumer et al. 1971, Youngblood et al. 1971, Youngblood and Blumer 1973), while terrestrial plants contain mainly $\mathrm{C}_{21}$ $\mathrm{C}_{35}$ n-alkanes (Eglinton et al. 1962, Eglinton and Hamilton 1963, Douglas and Eglinton 1966, Caldicott and Eglinton 1973) with a carbon preference index (CPI; Bray and Evans 1961) of 4-10 (Rrassell et al. 1978). Sediments containing petroleum residues exhibit an unresolved complex mixture (UCM) of hydrocarbons (Wakeham and Carpenter 1976, Wakeham and Farrington 1980) with n-alkanes having a CPI of 1 (Blumer and Sass 1972). The UCM is composed of a mixture of branched and cyclic, aliphatic and olefinic hydrocarbons.

Spatial variations of hydrocarbon concentrations in surficial sediments and vertical profiles in sediments are influenced by changes in material inputs and also by physical, chemical, and biological processes. For example, Hites et al. (1980) speculated that subsurface maxima in polyaromatic hydrocarbon (PAH) profiles in sediments reflected decreases in inputs caused by a change in home heating fuels from coal to oil and natural gas during the 1950s. Particles with 
different sizes and densities have unique hydrocarbon signatures (Thompson and Eglinton 1978, Wade and Quinn 1979, Prahl and Carpenter 1983). Therefore, hydrodynamics can influence hydrocarbon distributions in surficial sediments via differential particle dispersal (Prahl 1985). Biological processes can also alter hydrocarbon distributions. Several investigations have indicated that $\mathrm{n}$-alkanes in plankton are more susceptible to decomposition than those in terrestrial plant wax (Meyers et al. 1980a, Prahl et al. 1980, Wakeham et al. 1980, Bates et al. 1984). Furthermore, isoprenoid hydrocarbons such as pristane and phytane are not as readily degraded as straight-chain hydrocarbons (Blumer and Sass 1972). The UCM, comprising a complex mixture of branched and cyclic hydrocarbons, tends to persist in sediments. Feeding by oligochaetes can also alter profiles of hydrocarbons in sediments by providing a means of advecting substances from depths of $2-10 \mathrm{~cm}$ in sediments to the surface (Krezoski and Robbins 1985, Karickhoff and Morris 1985, Robbins 1986).

The purpose of our investigation was to examine the spatial distribution and vertical profiles of aliphatic hydrocarbons in sediment cores collected from the southern basin of Lake Michigan. Our intent was to (1) determine aliphatic hydrocarbon sources by using $n$-alkane distributions, (2) investigate variations of material inputs with time by examining hydrocarbon profiles in sediments, and (3) investigate hydrocarbon diagenesis by comparing downcore variations of $\mathrm{n}$-alkane homologs and isoprenoid hydrocarbons. Results from four cores taken within areas of fine-particle sedimentation in the southern basin are discussed. 


\section{SAMPLING AND ANALYSIS}

Sediments were collected in September 1980 at four sites (Table 1) located in the areas of fine-grained deposition in the southern basin of Lake Michigan (Fig. 1). The composition of sediments in these areas has been described by Cahill (1981) as silty clay. Undisturbed sediment cores $\left(250 \mathrm{~cm}^{2} \times 20 \mathrm{~cm}\right)$ were collected with a box coring device. The surfaces of all four cores were light brown and very flocculent, while deeper sections were grayish black and consolidated. Immediately after collection, the box cores were sectioned at $1-$ or $2-\mathrm{cm}$ intervals, and sections were transferred to solvent-rinsed glass jars and frozen.

Details of the analytical methodology have been described elsewhere (Doskey 1982, Doskey and Andren 1986). Briefly, sediments were freeze dried with a Virtis (model 10-100) freeze drier. The freeze drier was ruodified to eliminate contamination from vacuum pump oil and pump exhaust by isolating the pump in a vented hood and replacing the rubber vacuum ports on the drier with plastic plugs. Dried samples were pulverized with a mortar and pestle and then Soxhlet extracted with methylene chloride for 36 hours. Concentrated extracts were eluted through silica gel to isolate the aliphatic hydrocarbon fraction by following procedures by Tan (1979) and Macleod et al. (1977) as modified by Doskey (1982). Analysis was performed on a Hewlett Packard 5840 gas chromatograph equipped with a $25 \mathrm{~m} \times 0.2 \mathrm{~mm} \mathrm{SE}-30$ fused-silica capillary column (Scientific Glass Engineering, Austin, TX) and flame ionization detector. n-Alkanes, pristane, and phytane were quantified using authentic standards (Alltech Associates, Deerfield, IL). The UCM was quantified by measuring the unresolved area with a graphics tablet and by using the average response factor of the $n$-alkanes eluting above the UCM to convert the unresolved area to a UCM concentration. Total 
carbon and inorganic carbon were measured in dried samples by using a PerkinElmer model 203B Elemental Analyzer. Organic carbon was calculated by difference.

Precision for the individual $\mathrm{n}$-alkanes was $\pm 8 \%$. Procedural recoveries increased with carbon chain length and reached a maximum at $n-C_{20}$. The mean recovery for $\mathrm{n}-\mathrm{C}_{18}$ to $\mathrm{n}-\mathrm{C}_{32}$ was $78.8 \%$, while the mean for $\mathrm{n}-\mathrm{C}_{11}$ to $\mathrm{n}-\mathrm{C}_{17}$ was $62.6 \%$. To check possible evaporative losses of n-alkanes during freeze drying, our technique, which included extraction of freeze dried sediment with methylene chloride, was compared to a method in which wet sediment was extracted with methanol. The results of the two techniques were not significantly different, indicating that evaporative losses of $n$-alkanes during freeze drying are insignificant. Precision for the organic carbon analysis was $\pm 1.5 \%$.

\section{RESULTS}

Spatial variations of organic carbon concentrations in surficial sediments and changes in organic carbon levels in vertical profiles in sediments were evident at all four coring locations (Fig. 2a). Organic carbon concentrations in surficial sediments were highest at coring locations $6 \mathrm{~A}$ and $18 \mathrm{~A}$. To compensate for varying proportions of inorganic and organic material in texturally dissimilar samples, the aliphatic hydrocarbon concentrations reported here are normalized to organic carbon (Barrick et al. 1980). 


\section{Sources and Surficial Sediment Concentrations}

Several characteristics of aliphatic hydrocarbon distributions can be used to derive information on their origins. The carbon preference index (CPI), which is simply defined as the ratio of the mole fractions of the odd- to even-numbered homologs in a hydrocarbon distribution (Bray and Evans 1961), is one of these characteristics. The $\mathrm{CPI}_{14-20}$ in all sediment core sections varied from 1.3-1.7. The prominence of $n-C_{15}, n-C_{17}$, and $n-C_{19}$ in Lake Michigan sediments resulted in a CPI 14-20 value greater than 1 , which is typical of sediment hydrocarbons having a planktonic origin. These n-alkanes are prevalent in plankton, and the predominant homolog is species dependent (Clark and Blumer 1967, Blumer et al. 1971, Youngblood et al. 1971, Youngblood and Blumer 1973). Concentrations of $\mathrm{n}-\mathrm{C}_{17}$ in surficial sediments were greatest at coring locations $12 \mathrm{~A}$ and $24 \mathrm{~A}-\mathrm{A}$ and approximately twice the levels at locations $6 \mathrm{~A}$ and $18 \mathrm{~A}$ (Fig.4).

The CPI 20-32 of n-alkanes in all sediment core sections was 2.0-3.6. The slight predominance of odd carbon numbers over the range $\mathrm{C}_{20}-\mathrm{C}_{32}$ indicates that a fraction of the hydrocarbons have a terrestrial origin. The waxy coatings of terrestrial plants contain n-alkanes in the range $\mathrm{C}_{25}-\mathrm{C}_{33}$ (Eglinton et al. 1962, Eglinton and Hamilton 1963, Douglas and Eglinton 1966, Caldicott and Eglinton 1973) with a CPI of 4-10 (Brassell et al. 1978). Our samples exhibit CPIs lower than those of purely terrestrial plant waxes, suggesting that some contributions are from other sources. Concentrations of $n-C_{29}$ in surficial sediments were fairly uniform at all coring locations (Fig. 4).

The most prominent feature of the aliphatic hydrocarbon distribution in surficial sediments at all coring locations was a UCM. Concentrations of the 
UCM were greatest at locations $12 \mathrm{~A}$ and $24 \mathrm{~A}-\mathrm{A}$ (Fig. 2b). UCM concentrations were similar to the total $\mathrm{n}$-alkane concentrations at $6 \mathrm{~A}, 18 \mathrm{~A}$, and $24 \mathrm{~A}-\mathrm{A}$ and exceeded the level at 12A (Fig. 2c). The UCM has been observed in sediments from diverse environments and has been used as an indicator of petroleum pollution (Wakeham and Carpenter 1976, Wakeham and Farrington 1980). The CPI of nalkanes in petroleum is approximately one (Blumer and Sass 1972). Consequently, the CPI of a hydrocarbon assemblage having a planktonic and terrestrial plant wax origin should be decreased by additions of petroleum residues. Because the CPIs of the n-alkanes in Lake Michigan sediments are $>1$, petroleum residues cannot be the sole source of aliphatic hydrocarbons in southern basin sediments.

The $\mathrm{n}-\mathrm{C}_{29} / \mathrm{n}-\mathrm{C}_{17}$ ratio has been used to indicate relative strengths of allochthonous and autochthonous inputs of $\mathrm{n}$-alkanes to aquatic systems (Meyers et al. 1980b). Because $\mathrm{n}-\mathrm{C}_{17}$ is prevalent in plankton, it can be used as an indicator of authochthonous inputs of organic matter, while $n-C_{29}$ is abundant in terrestrial plant waxes and therefore can be used to represent allochthonous inputs. Spatial variations of the ratio are apparent (Fig. 2d). Coring locations 6A and 18A exhibit a greater predominance of allochthonous material.

A more quantitative way of apportioning sources of aliphatic hydrocarbons in sediments is to separate the $n$-alkanes into $C P I=1$ and $C P I=10$ members via a mass balance (Schneider et al. 1983, Doskey and Andren 1986). We define the total aliphatic hydrocarbon concentration as the sum of the concentrations of CPI=1 n-alkanes, CPI=10 n-alkanes, and the UCM. These groups represent contributions from plankton and petroleum, terrestrial plants, and petroleum, respectively. Aliphatic hydrocarbons in surficial sediments from coring locations 
$12 \mathrm{~A}$ and 24A-A exhibit the highest contribution by the UCM and the lowest contribution by the $\mathrm{CPI}=10 \mathrm{n}$-alkanes (Fig. 3 ). Contributions by the $\mathrm{CPI}=10$ and $\mathrm{CPI}=1 \mathrm{n}$-alkanes at these locations are nearly equal. Terrestrial $\mathrm{n}$-alkanes represent a greater proportion of the aliphatic hydrocarbons in sediments at stations $6 \mathrm{~A}$ and $18 \mathrm{~A}$. This result agrees nicely with trends indicated by the $\mathrm{n}$ $\mathrm{C}_{29} / \mathrm{n}-\mathrm{C}_{17}$ ratios.

\section{Vertical Profiles}

The UCM concentrations in southern basin sediments approached background levels ( $10 \mu \mathrm{g} / \mathrm{g} \mathrm{OC}$ ) at different depths in each core (Fig. 2b). Because the UCM has been attributed to anthropogenic inputs, this feature of the UCM profiles may indicate that sedimentation rates at coring locations $12 \mathrm{~A}$ and $24 \mathrm{~A}-\mathrm{A}$ are greater than those at $6 \mathrm{~A}$ and $18 \mathrm{~A}$. The $\mathrm{UCM}$ profiles for cores $12 \mathrm{~A}$ and $24 \mathrm{~A}-\mathrm{A}$ both contained subsurface maxima (Fig. 2b). Maxima in cores $6 \mathrm{~A}$ and $18 \mathrm{~A}$ could be obscured by wide sectioning intervals because sedimentation rates at these locations are lower than the other coring sites. Swackhamer (1985) determined a linear sedimentation rate and a mass sedimentation rate of $0.066 \mathrm{~cm} / \mathrm{yr}$ and $0.016 \mathrm{~g} / \mathrm{cm}^{2} \cdot \mathrm{yr}$, respectively, for a duplicate core of $18 \mathrm{~A}$. This result is in good agreement with the value of $0.012 \mathrm{~g} / \mathrm{cm}^{2} \cdot \mathrm{yr}$ reported by Robbins and Edgington (1975) for this location. Applying Swackhamer's data to UCM concentrations reported here indicates that the UCM first appeared about 100 years before 1980 at coring location 18A. For a mass sedimentation rate of $0.016 \mathrm{~g} / \mathrm{cm}^{2} \cdot \mathrm{yr}$, the pre-1900 flux of the UCM was approximately $6 \mathrm{ng} / \mathrm{cm}^{2} \cdot \mathrm{yr}$, and the $1980 \mathrm{flux}$ is about 96 $\mathrm{ng} / \mathrm{cm}^{2} \cdot \mathrm{yr}$. The input of petroleum residues to the southern basin of Lake 
Michigan has apparently increased by more than an order of magnitude since 1900.

All four cores exhibited a decrease of $n-C_{17}$ relative to pristane within the top few centimeters (Figs. 4a-4d). Profiles of $n-C_{29}$, an $n$-alkane attributed to terrestrial plant wax, are similar to that of $\mathrm{n}-\mathrm{C}_{17}$ in the the upper $3 \mathrm{~cm}$ of each core except 18A (Figs. 4a-4d). Subsurface maxima are present in three of the four cores. The $\mathrm{n}-\mathrm{C}_{2} 9$ maximum in core $24 \mathrm{~A}-\mathrm{A}$ coincides with the subsurface maximum exhibited by the UCM.

\section{DISCUSSION}

Several processes may be responsible for spatial variations in the aliphatic hydrocarbon composition of southern basin sediments. Thompson and Eglinton (1978) fractionated sediments by size and found that planktonic n-alkanes and the UCM were concentrated in the silt/clay fraction $(<66 \mu \mathrm{m})$, while plant wax $\mathrm{n}$-alkanes were concentrated in a coarse-particle fraction $(>125 \mu \mathrm{m})$ containing terrestrial plant detritus. Organic carbon concentrations were highest and were similar in the coarse-particle and silt/clay fractions. It is unlikely that hydrodynamics is responsible for dissimilarities in hydrocarbon distributions at the four coring locations because they are all within active zones of sedimentation. However, the UCM data (Fig. 2b) indicate that mass sedimentation rates at locations $12 \mathrm{~A}$ and $24 \mathrm{~A}-\mathrm{A}$ are more rapid than they are at locations $6 \mathrm{~A}$ and $18 \mathrm{~A}$. Sediments in high-sedimentation zones receive greater inputs of inorganic material than those in low-sedimentation zones. This may explain why organic 
carbon concentrations in surficial sediments at $6 \mathrm{~A}$ and $18 \mathrm{~A}$ were greater than those observed at $12 \mathrm{~A}$ and $24 \mathrm{~A}-\mathrm{A}$.

Microbial decomposition has probably altered the planktonic n-alkane distribution of surficial sediment. Several investigations have indicated that $\mathrm{n}$-alkanes associated with plankton are more susceptible to decomposition than those associated with terrestrial plant wax (Meyers et al. 1980a, Prahl et al. 1980, Wakeham et al. 1980, Bates et al. 1984). Biodegradation of hydrocarbons in aerobic sediments is also more rapid than microbial decomposition of hydrocarbons in anaerobic sediments (Jobson et al. 1979). n-Alkane distributions in sediments having slow sedimentation rates or deep mixing zones would exhibit a lower planktonic n-alkane contribution because sediments within this layer spend a longer time in the aerated zone. This may explain why surficial sediments at $6 \mathrm{~A}$ and $18 \mathrm{~A}$ have lower concentrations of $\mathrm{n}-\mathrm{C}_{17}$ than at locations $12 \mathrm{~A}$ and $24 \mathrm{~A}-\mathrm{A}$. Planktonic $\mathrm{n}$-alkane fluxes at $12 \mathrm{~A}$ and $24 \mathrm{~A}-\mathrm{A}$ may be greater also because of the higher primary productivity of nearshore areas.

Terrestrial hydrocarbon concentrations in surficial sediments were fairly uniform (Figs. 4a-4d). However, contributions of terrestrial hydrocarbons were greatest in the low-sedimentation areas (Fig. 3). Biodegradation of the planktonic fraction apparently has enriched the aliphatic hydrocarbon distribution in plant wax n-alkanes at locations $6 \mathrm{~A}$ and $18 \mathrm{~A}$.

Both the UCM concentrations and contributions were greatest at locations $12 \mathrm{~A}$ and $24 \mathrm{~A}-\mathrm{A}$ and appear to be correlated with planktonic n-alkane concentrations. This correlation agrees with the data of Thompson and Eglinton (1978), who found that planktonic n-alkane and UCM concentrations were highest 
in the silt/clay fraction. The UCM may enter Lake Michigan as an oily residue that partitions to organic-carbon-rich particles. Wade and Quinn (1979) speculated that the UCM associates with fine particles because of their large surface area.

Verticle profiles of hydrocarbons in sediments may also be affected by several processes. Subsurface maxima have been observed in profiles of energyrelated substances. Goldberg et al. (1981) found a subsurface maximum in the profile for charcoal particles $>38 \mu \mathrm{m}$ in diameter in a core taken from a depositional region in the southern basin of Lake Michigan. Charcoals in this size range are products of coal combustion. The maximum occurred in sediments deposited in about 1955, the same period in which Hites et al. (1980) hypothesized that subsurface maxima in PAH profiles reflect decreases in inputs caused by a change in home heating fuels from coal to oil and natural gas. Helfrich and Armstrong (1986) observed subsurface maxima in PAH profiles in sediments from the southern basin of Lake Michigan. Like the PAHs, the UCM has been detected in unburned coal and vehicle exhaust (Tripp et al. 1981, Simoneit 1984). The UCM has also been found in aerosols and precipitation collected in the Midwest region (Doskey and Andren 1986, Meyers and Hites 1982). Consequently, subsurface maxima in UCM profiles may reflect decreases in material inputs.

Biological activity may also produce subsurface maxima in profiles. Oligochaetes in sediments selectively feed on fine particles containing high concentrations of organic matter (McCall and Fisher 1980). These organisms feed at depths of 2-10 cm in sediments and eject material at the sediment surface. Subsurface maxima in profiles of various substances have been shown to be 
produced by this mechanism (Karickhoff and Morris 1985, Krezoski and Robbins 1985, Robbins 1986). Thompson and Eglinton (1978) found that the UCM was associated with organic-carbon-rich, fine particles. Consequently, UCM profiles in Lake Michigan sediments may have been altered by this mechanism. Thompson and Eglinton (1978) also found that planktonic n-alkanes were concentrated in the same size fraction. The dissimilarity between profiles of the planktonic n-alkanes and the UCM is probably caused by recalcitrance of the UCM to biodegradation.

Microbial decomposition of the planktonic n-alkanes is illustrated by the decrease of $n-C_{17}$ relative to pristane within the top few centimeters of each core. Isoprenoid hydrocarbons such as pristane and phytane are not as readily degraded as straight-chain hydrocarbons (Blumer and Sass 1972). Differences in $\mathrm{n}-\mathrm{C}_{17}$ and pristane concentrations in deeper sections of the cores become constant, indicating that $n-C_{17}$ is being preserved within the anoxic layers of the sediment. Anaerobic decomposition of hydrocarbons is much slower than aerobic decomposition (Jobson et al. 1979).

\section{CONCLUSIONS}

The prominence of $\mathrm{n}-\mathrm{C}_{15}, \mathrm{n}-\mathrm{C}_{17}$, and $\mathrm{n}-\mathrm{C}_{19}$; a slight odd-carbon-number predominance within the range $\mathrm{C}_{20}-\mathrm{C}_{32}$; and an unesolved complex mixture (UCM) all suggest that aliphatic hydrocarbons in southern basin sediments originate from planktonic, terrigenous, and petroleum residue sources. Sediments from coring locations $24 \mathrm{~A}-\mathrm{A}$ and $12 \mathrm{~A}$ contained more petroleum residues and planktonic hydrocarbons and exhibited less terrigenous character 
than sediments collected at locations $6 \mathrm{~A}$ and $18 \mathrm{~A}$. Greater biodegradation of planktonic n-alkanes within the aerobic, mixed zone in locations having siow sedimentation rates is believed to be responsible for the low planktonic and high plant wax contributions at $6 \mathrm{~A}$ and $18 \mathrm{~A}$. Large contributions of the UCM at locations $12 \mathrm{~A}$ and $24 \mathrm{~A}-\mathrm{A}$ probably result from the association of the UCM and planktonic n-alkanes with particles of the same size or density.

Analysis of the UCM profile in a dated sediment core from the deepest area of the southern basin indicated that petroleum residue inputs have increased since 1900. The UCM flux has increased by an order of magnitude, from approximately $6 \mathrm{ng} / \mathrm{cm}^{2} \cdot \mathrm{yr}$ before 1900 to about $96 \mathrm{ng} / \mathrm{cm}^{2} \cdot \mathrm{yr}$ in 1980 . The UCM profiles at two of the coring locations exhibited subsurface maxima that may be the result of reduced inputs of combustion products or feeding by oligochaetes. Unlike UCM profiles, profiles of terrestrial and planktonic n-alkanes exhibited surface maxima. Downcore decreases of $n-C_{17}$ relative to pristane suggest that $n$ $\mathrm{C}_{17}$ is degraded within the aerobic, mixed zone of the sediments.

\section{ACKNOWLEDGEMENTS}

We thank the captain and crew of the RV Roger Simons for their assistance with sampling and also Norman Draeger for laboratory assistance in the early phases of this work. Rebecca Spencer's diligence in typing the manuscript and Karen Haugen's help with editing are greatly appreciated. This investigation was supported by the University of Wisconsin Sea Grant Institute through Federal Grant NA 800-AA-00086, Project R/MW-13 from the National Sea Grant College Program, National Oceanic and Atmospheric Administration, U. S. 
Department of Commerce. The writing of this manuscript was sponsored by the U.S. Departmont of Energy, Office of Energy Research, Office of Health and Environmental Research, under contract W-31-109-ENG-38.

\section{REFERENCES}

Barrick., R.C., Hedges, J.I., and Peterson, M.L. 1980. Hydrocarbon geochemistry of the Puget Sound region-I. Sedimentary acyclic hydrocarbons. Geochim. Cosmochim. Acta 44:1349-1362.

Bates, T.S., Hamilton, S.E., and Cline, J.D. 1984. Vertical transport and sedimentation of hydrocarbons in the Central Main Basin of Puget Sound, Washington. Environ. Sci. Technol. 18:299-305.

Blumer, M., Guillard, R.R.L., and Chase, T. 1971. Hydrocarbons of marine phytoplankton. Mar. Biol. 8:183-189.

and Sass, J. 1972. Indigenous and petroleum-derived hydrocarbons in a polluted sediment. Mar. Pollut. Bul. 3:92-94.

Brassell, S.C., Eglinton, G., Maxwell, J.R., and Philp, R.P. 1978. Natural background alkanes in the aquatic environment. In Aquatic Pollutants: Transformation and Biological Effects, eds. O. Hutzinger, I.H. Lelyveld, and B.C.J. Zoetman, pp. 69-86. New York: Pergammon Press.

Bray, E.E., and Evans, E.D. 1961. Distribution of n-paraffins as a clue to recognition of source beds. Geochim. Cosmochim. Acta 22:2-15.

Cahill, R.A. 1981. Geochemistry of Recent Lake Michigan Sediments. Champaign: Illinois State Geological Survey. Circular 517.

Caldicott, A.B., and Eglinton, G. 1973. Surface waxes. In Phytochemistry III: Inorganic Elements and Special Groups of Chemicals, ed. L.P. Miller, pp. 162-194. New York: Van Nostrand/Reinhold.

Clark R.C., Jr., and Blumer, M. 1967. Distribution of n-paraffins in marine organisms and sediment. Limnol. Oceanogr. 12:79-87.

Doskey, P.V. 1982. Atmospheric fluxes and the geochemistry of n-alkanes in Crystal Lake (Vilas County), Wisconsin. Ph.D. dissertation, University of Wisconsin, Madison, Wisconsin. 
and Andren, A.W. 1986. Particulate- and vapor-phase n-alkanes in the northern Wisconsin atmosphere. Atmos. Environ. 20:1735-1744.

Douglas, A.G., and Eglinton, G. 1966. The distribution of alkanes. In Comparative Phytochemistry, ed. T. Swain, pp. 57-77. London: Academic Press.

Eglinton, G., Gonzalez, A.G., Hamilton, R.J., and Raphael, R.A. 1962. Hydrocarbon constituents of the wax coatings of plant leaves - a taxonomic survey. Phytochemistry 1:89-102.

and Hamilton, R.J. 1963. The distribution of alkanes. In Chemical Plant Taxonomy, ed. T. Swain, pp. 187-217. London: Academic Press.

Giger, W., Reinhard, M., Schaffner, C., and Stumm, W. 1974. Petroleum-derived and indigenous hydrocarbons in recent sediment of Lake Zug, Switzerland. Environ. Sci. Technol. 8:454-455.

, Schaffner, C., and Wakeham, S.G. 1980. Aliphatic and olefinic hydrocarbons in recent sediments of Greifensee, Switzerland. Geochim. Cosmochim. Acta 44:119-129.

Goldberg, E.D., Hodge, V.F., Griffin, J.J., Koide, M., and Edgington, D.N. 1981. Impact of fossil fuel combustion on the sediments of Lake Michigan. Environ. Sci. Technol. 15:466-471.

Helfrich, J., and Armstrong, D.E. 1986. Polycyclic aromatic hydrocarbons in sediments of the Southern Basin of Lake Michigan. J. Great Lakes Res. 12:192-199.

Hites, R.A., Laflamme, R.E., Windsor, J.G., Jr., Farrington, J.W., and Deuser, W.G. 1980. Polycyclic aromatic hydrocarbons in an anoxic sediment core from the Pettaquamscutt River (Rhode Island, U.S.A.), Geochim. Cosmochim. Acta 44:873-878.

Jobson, A.M., Cook, F.D., and Westlake, D.W.S. 1979. Interaction of aerobic and anaerobic bacteria in petroleum biodegradation. Chem. Geol. 24:355-365.

Karickhoff, S.W., and Morris, K.R. 1985. Impact of tubificid oligochaetes on pollutant transport in bottom sediments. Environ. Sci. Technol. 19:51-56.

Krezoski, J.R., and Robbins, J.A. 1985. Vertical distribution of feeding and particle-selective transport of ${ }^{137} \mathrm{Cs}$ in lake sediments by lumbriculid oligochaetes. J. Geophys. Res. 90:11,999-12,006.

Macleod, W.D., Jr., Brown, D.W., Jenkins, R.G., Ramos, L.S., and Henry, V.D. 1977. Petroleum Hydrocarbons in the Northern Puget Sound Area-A Pilot Design Study. National Oceanic and Atmospheric Administration - U.S. 
Environmental Protection Agency Report NOAA TM ERL MESA-8 and EPA 600/7-77-098, Seattle, Washington.

McCall, P.L., and Fisher, J.B. 1980. Effects of tubificid oligochaetes on physical and chemical properties of Lake Erie sediments. In Aquatic Oligochaete Biology, eds. R.O.Brinkhurst and D.G. Cook, pp. 253-318. New York: Plenum.

Meyers, P.A., and Takeuchi, N. 1979. Fatty acids and hydrocarbons in surficial sediments of Lake Huron. Org. Geochem. 1:127-139.

, Edwards, S.J., and Eadie, B. 1980a. Fatty acid and hydrocarbon content of settling sediments in Lake Michigan. J. Great Lakes Res. 6:331-337.

, Bourbonniere, R.A., and Takeuchi, N. 1980b. Hydrocarbons and fattyacids in two cores of Lake Huron sediments. Geochim. Cosmochim. Acta 44:1215-1221.

, and Hites, R.A. 1982. Extractable organic compounds in Midwest rain and snow. Atmos. Environ. 16:2169-2175.

Prahl, F.G. 1985. Chemical evidence of differential particle dispersal in the southern Washington coastal environment. Geochim. Cosmochim. Acta 49:2533-2539.

, Bennett, J.T., and Carpenter, R. 1980. The early diagenesis of aliphatic hydrocarbons and organic matter in sedimentary particulates from Dabob Bay, Washington. Geochim. Cosmochim. Acta 44:1967-1976.

, and Carpenter, R. 1983. Polycyclic aromatic hydrocarbon (PAH) - phase associations in Washington coastal sediment. Geochim. Cosmochim. Acta 47:1013-1023.

Robbins, J.A. 1986. A model for particle-selective transport of tracers in sediments with conveyor belt deposit feeders, J. Geophys. Res 91:8542-8558. , and Edgington, D.N. 1975. Determination of recent sedimentation rates in Lake Michigan using $210 \mathrm{~Pb}$ and $137 \mathrm{Cs}$. Geochim. Cosmochim. Acta 39:285-304.

Schneider, J.K., Gagosian, R.B., Cochran, J.K., and Trull, T.W. 1983. Particle size distributions of $n$-alkanes and $210 \mathrm{~Pb}$ in aerosols off the coast of Peru. Nature 304:429-432.

Simoneit, B.R.T. 1984. Organic matter of the troposphere-III. Characterization and sources of petroleum and pyrogenic residues in aerosols over the western United States. Atmos. Environ. 18:51-67. 
Swackhamer, D.L. 1985. The role of water-particle partitioning and sedimentation in controlling the fate and transport of PCBs in lakes. Ph.D. dissertation, University of Wisconsin, Madison, Wisconsin.

Tan, Y.L. 1979. Rapid simple sample preparation techniques for analyzing polynuclear aromatic hydrocarbons in sediments by gas chromatographymass spectrometry. J. Chromatogr. 176:319-327.

Thompson, S., and Eglinton, G. 1978. The fractionation of a recent sediment for organic geochemical analysis. Geochim. Cosmochim. Acta 42:199-207.

Tripp, B.W., Farrington, J.W., and Teal, J.M. 1981. Unburned coal as a source of hydrocarbons in surface sediments. Mar. Pollut. Bul. 12:122-126.

Wade, T.L., and Quinn, J.G. 1979. Geochemical distribution of hydrocarbons in sediments from mid-Narragansett Bay, Rhode Island. Org. Geochem. 1:157-167.

Wakeham, S.G., and Carpenter, R. 1976. Aliphatic hydrocarbons in sediments of Lake Washington. Limnol. Oceanogr. 21:711-723.

, and Farrington, J.W. 1980. Hydrocarbons in contemporary aquatic sediments. In Contaminants and Sediments, Volume 1., ed. R.A.

Baker, pp. 3-32. Ann Arbor: Ann Arbor Science.

, Farrington, J.W., Gagosian, R.B., Lee, C., DeBarr, H., Nigrelli, G.E., Tripp, B.W., Smith, S.E., and Frew, N.M. 1980. Organic matter fluxes from sediment traps in the equatorial Atlantic Ocean. Nature 286:798-800.

Youngblood, W.W., Blumer, M., Guillard, R.L., and Fiore, F. 1971. Saturated and unsaturated hydrocarbons in marine benthic algae. Mar. Biol. 8:190201. , and Blumer, M. 1973. Alkanes and alkenes in marine benthic algae. Mar. Bio. 21:163-172. 
Doskey and Andren

Table 1. Lake Michigan sampling stations.

\begin{tabular}{cllc}
\hline & \multicolumn{2}{c}{ Coordinates } & \\
\cline { 2 - 3 } Station & Longitude & Latitude & $\begin{array}{c}\text { Water Depth } \\
(\mathrm{m})\end{array}$ \\
\hline & & & \\
\hline $6 \mathrm{~A}$ & $86^{\circ} 39^{\prime} 00^{\prime} \mathrm{W}$ & $42^{\circ} 00^{\prime} 00^{\prime \prime} \mathrm{N}$ & 27 \\
$12 \mathrm{~A}$ & $86^{\circ} 35^{\prime} 00^{\prime \prime} \mathrm{W}$ & $42^{\circ} 23^{\prime} 00^{\prime \prime} \mathrm{N}$ & 62 \\
$18 \mathrm{~A}$ & $87^{\circ} 00^{\prime} 00^{\prime \prime} \mathrm{W}$ & $42^{\circ} 44^{\prime} 00^{\prime \prime} \mathrm{N}$ & 161 \\
$24 \mathrm{~A}-\mathrm{A}$ & $86^{\circ} 24^{\prime} 40^{\prime \prime} \mathrm{W}$ & $43^{\circ} 03^{\prime} 00^{\prime \prime} \mathrm{N}$ & 80 \\
\hline
\end{tabular}




\section{LIST OF FIGURES}

Fig. 1. Locations of Lake Michigan sampling stations.

Fig. 2. Concentrations (on the basis of dry sediment) of (a) organic carbon (OC), (b) UCM, (c) total n-alkanes $\left(\mathrm{C}_{11}-\mathrm{C}_{32}\right)$, and (d) $\mathrm{n}-\mathrm{C}_{29} / \mathrm{n}-\mathrm{C}_{17}$ ratio vs. depth in four Lake Michigan sediment cores.

Fig. 3. Contributions of the UCM, CPI=10 n-alkanes, and CPI=1 n-alkanes to the aliphatic hydrocarbons in the surface layers of four Lake Michigan sediment cores.

Fig. 4. Concentrations (on the basis of organic carbon ) of $n-C_{17}$, pristane (Pr), and $n-C_{29}$ vs. depth in four Lake Michigan sediment cores: (a) 6A, (b) $12 \mathrm{~A}$, (c) $18 \mathrm{~A}$, and (d) $24 \mathrm{~A}-\mathrm{A}$. 
Fij.l.

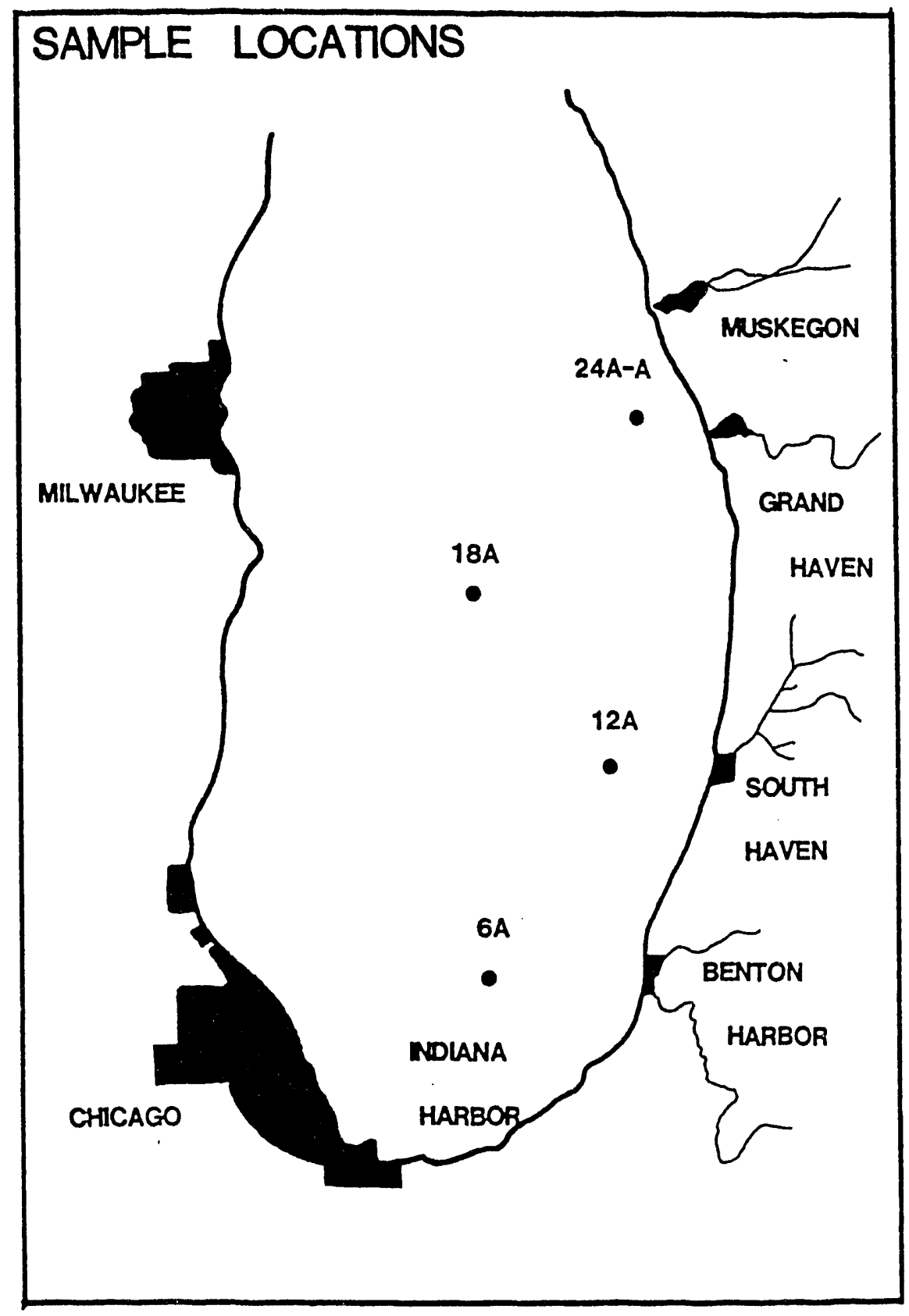



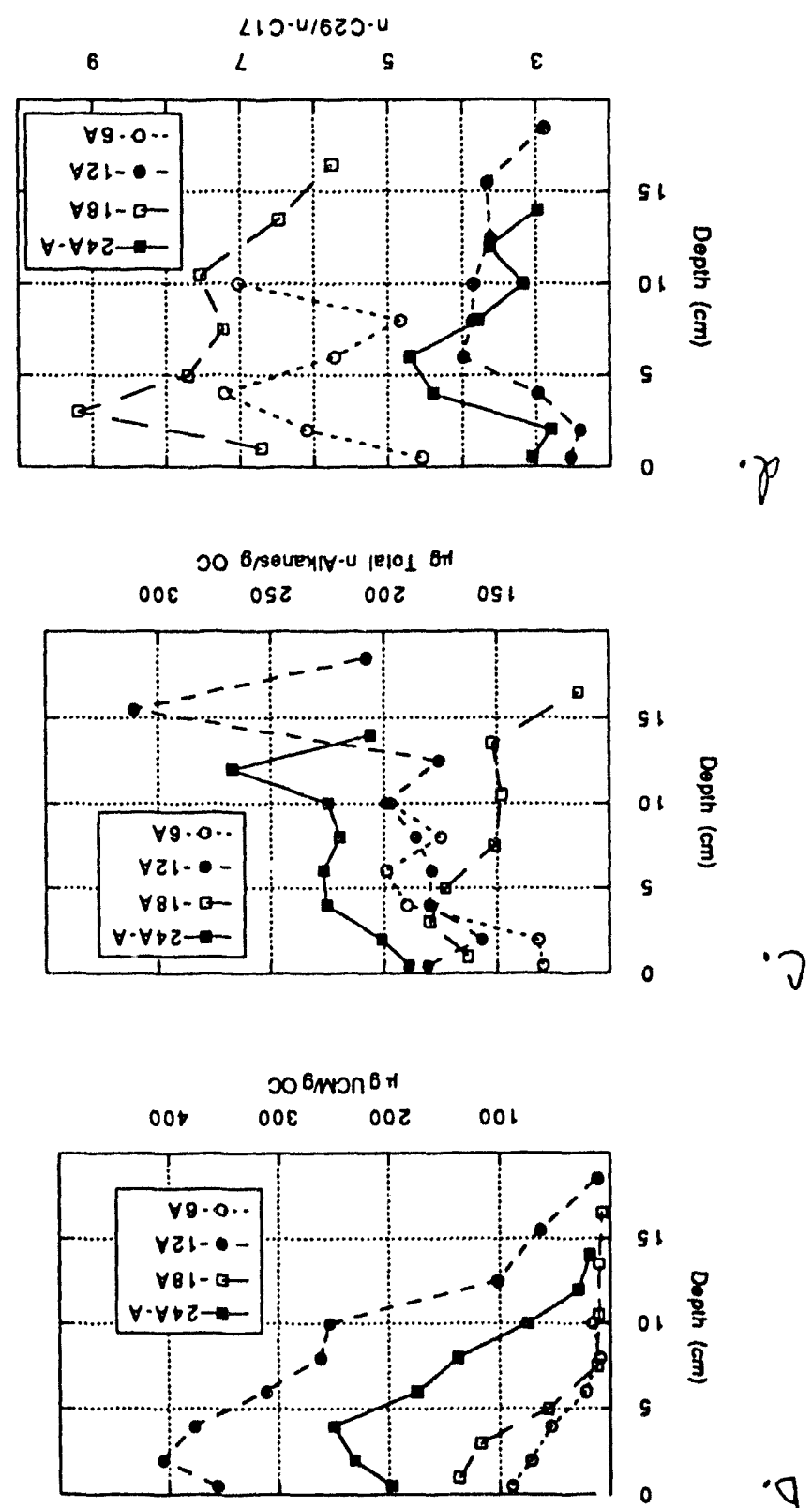

$\cdot 9$

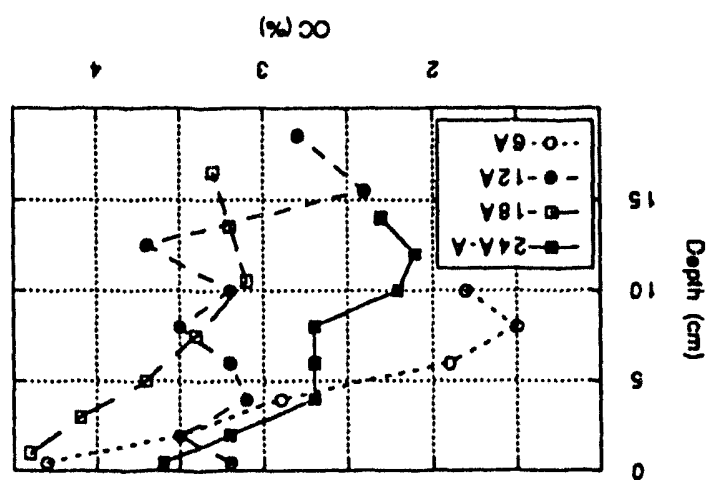

$\cdot 0$

$2 \cdot \operatorname{l} \cdot]$ 
$F_{i j} 3$.

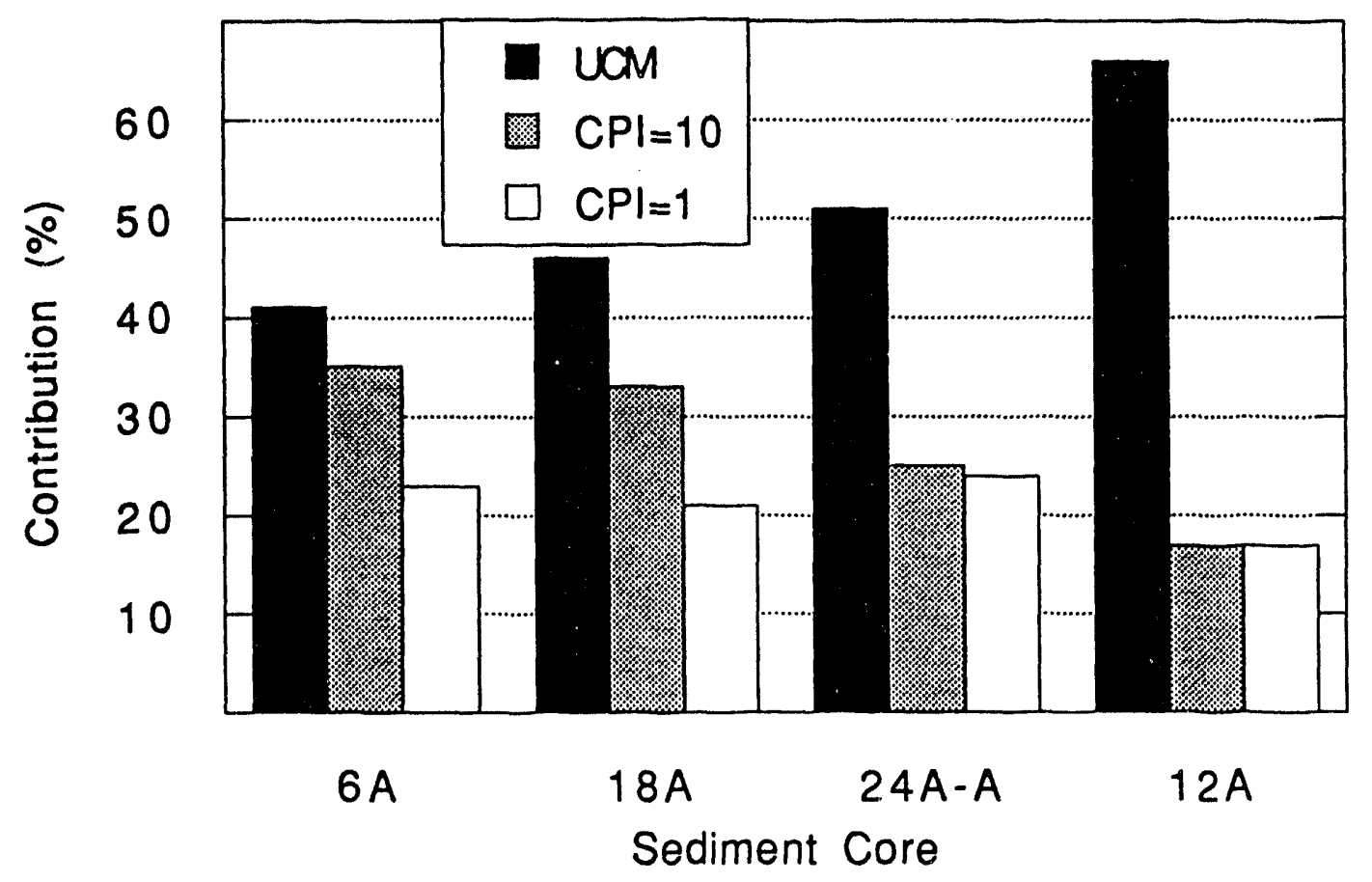


Fig. 4.

a.

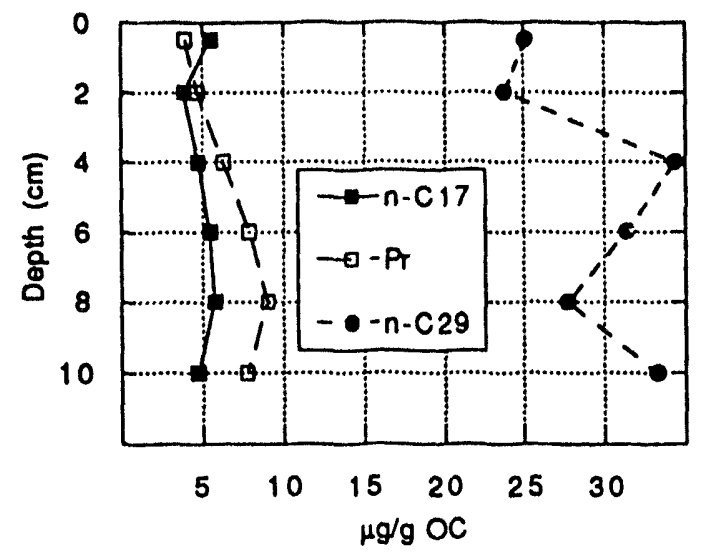

$b$.

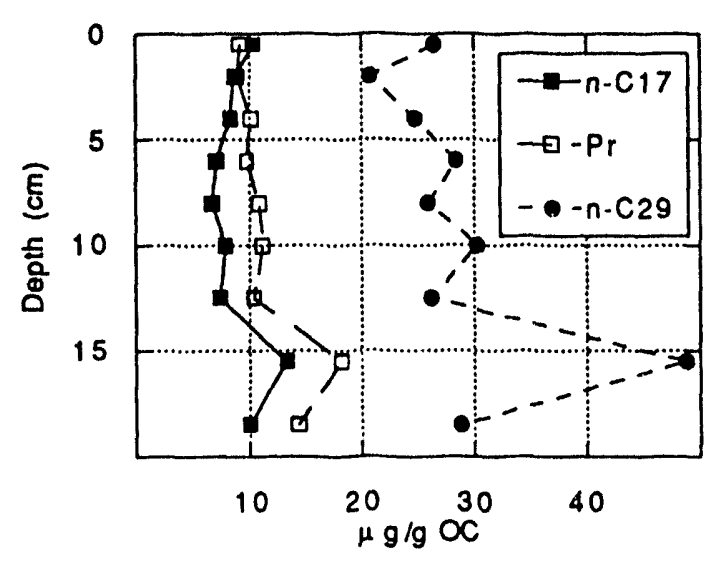

C.
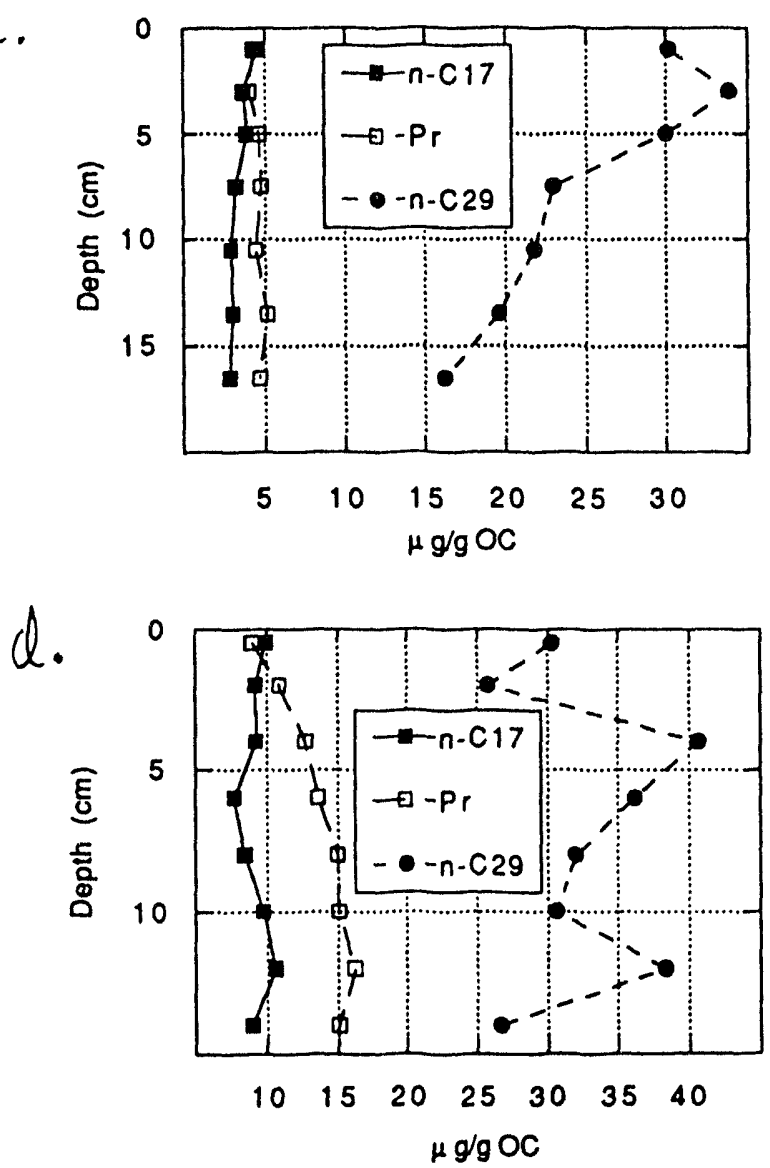

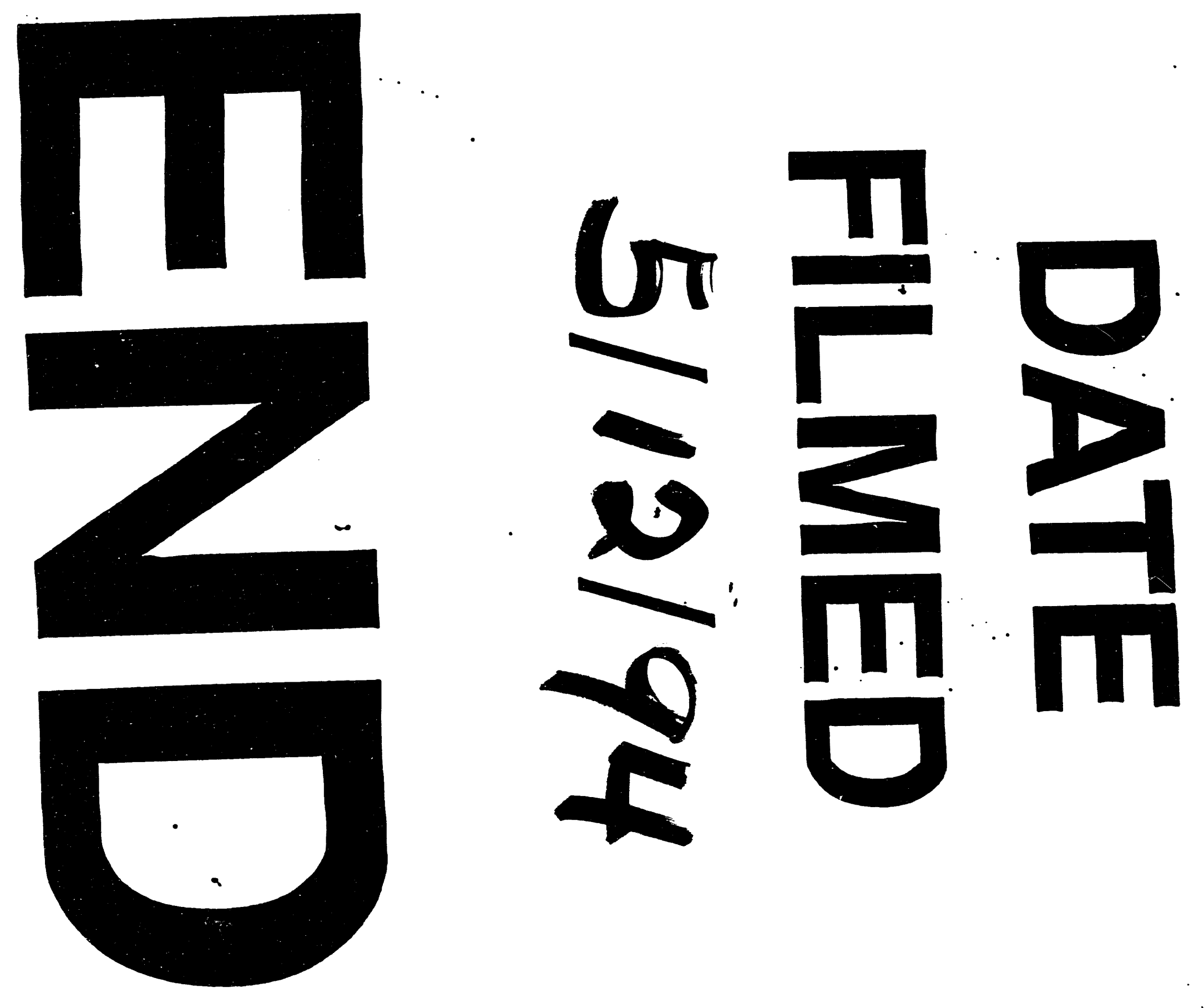